\title{
PEMODELAN PROSES BISNIS REGISTRASI PENGISIAN KRS UNIVERSITAS SAM RATULANGI MANADO
}

\author{
Reskyana Tanggo ${ }^{1)}$; Sheila Claudy Riady ${ }^{2)}$ \\ 1), 2) Program Studi Teknik Informatika, Fakultas Teknik, Universitas Sam Ratulangi \\ 1) kikiana_03@yahoo.com; ${ }^{2)}$ sheila_riady@yahoo.com
}

\begin{abstract}
ABSTRAK
Universitas Sam Ratulangi adalah sebuah Universitas negeri yang ada di Sulawesi Utara. Berdasarkan surat keputusan Presiden Republik Indonesia nomor 277 tertanggal 14 September 1965, ditetapkan pengesahan Universitas Sam Ratulangi atau yang biasa disebut Unsrat. [1] Untuk mempermudah mahasiswa dalam mengontrak mata kuliah, maka Universitas Sam Ratulangi mengadakan pengisian Kartu Rencana Studi (KRS) dalam periode tertentu. Ada pengisian secara manual dan secara online. Dalam paper ini, kami akan menyajikan proses pengisian KRS secara manual maupun online dalam format BPMN. BPMN adalah representasi grafis untuk menentukan proses bisnis dalam suatu pemodelan proses bisnis. Melalui BPMN pemodelan proses pengisian KRS akan lebih mudah dipahami dan dalam penyajiannya lebih rapih dan rinci.
\end{abstract}

Kata kunci: Universitas Sam Ratulangi, BPMN, KRS

\section{PENDAHULUAN}

Universitas Sam Ratulangi (Unsrat) merupakan universitas negeri di Provinsi Sulawesi Utara. Pada tanggal 14 September 1965 Unsrat yang telah ditetapkan sebagai salah satu Perguruan Tinggi Negeri (PTN) terdiri dari tujuh fakultas. [1]

Dari tahun ke tahun Universitas Sam Ratulangi berusaha meningkatkan kinerjanya di bidang pendidikan. Universitas Sam Ratulangi membuat agar para mahasiswa bisa merasa nyaman dan dimudahkan, khususnya dalam proses pengisian KRS. Dalam paper ini akan dibahas cara pengisian KRS manual dan Online yang pernah dan sedang dijalankan oleh Universitas Sam Ratulangi. Pemodelan dalam proses pengisian KRS tersebut akan kami sajikan dengan BPMN untuk mempermudah para pembaca untuk mengerti. [1]

\section{BPMN}

BPMN adalah singkatan dari Business Process Modeling Notation, yaitu suatu metodologi baru yang dikembangkan oleh Business Process Modeling Initiative sebagai suatu standard baru pada pemodelan proses bisnis, dan juga sebagai alat desain pada sistem yang kompleks seperti sistem eBusiness yang berbasis pesan (message-based).[2]

Tujuan utama dari BPMN adalah menyediakan notasi yang mudah digunakan dan bisa dimengerti oleh semua orang yang terlibat dalam bisnis, yang meliputi bisnis analis yang memodelkan proses bisnis, pengembang teknik yang membangun sistem yang melaksanakan bisnis, dan berbagai tingkatan manajemen yang harus dapat membaca dan memahami proses diagram dengan cepat sehingga dapat membantu dalam pengambilan keputusan.[2]
Notasi BPMN yang baru juga dirancang untuk sifat sistem berbasis layanan web. BPMN dapat memodelkan pesan kompleks yang dilewatkan diantara pelaku bisnis atau bagian dari pelaku bisnis, kejadian yang menyebabkan pesan dilewatkan, dan aturan bisnis yang membatasi kejadian tersebut. BPMN memugkinkan proses bisnis dipetakan ke bahasa eksekusi bisnis berbasis XML seperti BPEL4WS (Business Process Execution Language for Web Service) dan BPML (Business Process Modeling Language). [2].

\subsection{Kategori Elemen-elemen BPMN}

Terdapat 4 kategori dari elemen-elemen dalam BPMN, yaitu:

1. Flow Objects

a. Events, sebuah event direpresentasikan dengan lingkaran. Events dapat berupa Start, Intermediate, atau End.

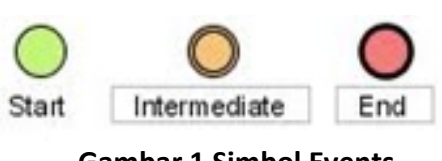

b. Acuvitues, seduan akuvitas direpresentasikan dengan persegi dengan sudut melingkar dan memperlihatkan pekerjaan yang harus dilakukan.

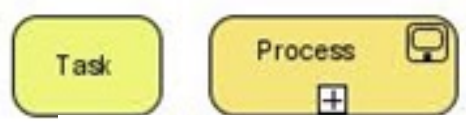

Gambar 2. Simbol Activities 
c. Gateways, sebuah gateway direpresentasikan dengan belah ketupat dan memperlihatkan pilihan yang berbeda. Gateway juga menjelaskan mengenai percabangan dan penggabungan dari path yang ada.
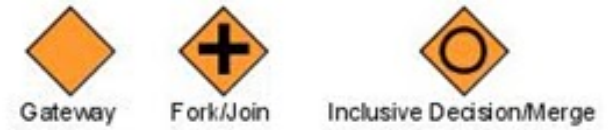

Gambar 3. Simbol Gateways

2. Connecting Objects

a. Sequence Flow, sequence flow direpresentasikan dengan garis lurus dengan panah tertutup dan menjelaskan mengenai urutan aktivitas yang akan dijalankan.

\section{Gambar 4. Sequance Flow}

b. Message Flow, message flow direpresentasikan dengan garis putusputus dan panah terbuka. Message flow menjelaskan pertukaran pesan yang sedang terjadi.

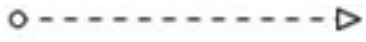

Gambar 5. Message Flow

Association, association direpresentasikan dengan garis putusputus. Association digunakan untuk mengasosiasikan sebah artifak, data, maupun flow object.

\section{Gambar 6. Association}

\section{Swimlanes}

a. Pool, pool direpresentasikan dengan persegi besar yang didalamnya dapat berisi flow objects, connecting object, maupun artifak.

b. Lane, lane merupakan bagian lebih mendetail dari pool.

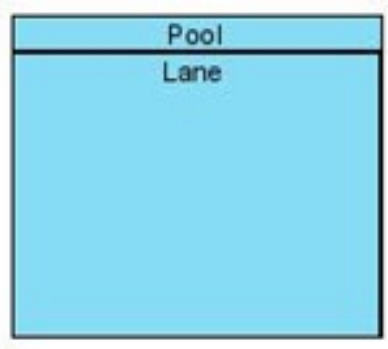

Gambar 7. Swimlanes a. Data Objects, data object digunakan untuk menjelaskan mengenai data yang dibutuhkan atau dihasilkan dari sebuah aktivitas.

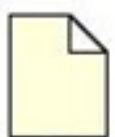

\section{Gambar 8. Data Objects}

b. Group, group direpresentasikan dalam persegi dengan sudut melingkar dan garis luar putus-putus. Group untuk melakukan grouping aktivitas.

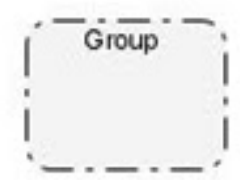

Gambar 9. Group

\section{Pemodelan Pengisian KRS dengan BPMN}

Pada bagian ini, kami akan menjelaskan proses pengisian KRS secara manual maupun online.

\subsection{Analisis Sistem Pengisian KRS Manual}

Berdasarkan hasil analisis pada proses pengisian KRS Manual Fakultas Teknik Universitas Sam Ratulangi kami telah membuat tahap-tahap dalam proses pengisian KRS tersebut. Tahap-tahapnya sebagai berikut:

1. Membayar SPP. Para mahasiswa diwajibkan untuk membayar SPP terlebih dahulu. Setelah membayar SPP, mahasiswa diminta untuk melkukan registrasi pada pihak Fakultas. Registrasi ini dilakukan dengan cara memberikan bukti pembayaran SPP (dalam bentuk struk pembayaran dari Bank).

2. Mengambil kertas pengisian KRS. Tiap mahasiswa wajib mengambil kertas yang telah disediakan di kantor jurusan untuk mengisi KRS.

3. Pihak kantor jurusan memberikan kertas pengisian KRS.

4. Membuka portal akademik. Tiap mahasiswa telah diberikan Username yang berupa NRI dan password (ditentukan sendiri) untuk mengakses portal akademik untuk kelancaran proses pengisian KRS.

5. Memasukkan username dan password. Mahasiswa harus mengisi username dan password untuk dapat membuka portal dan mengisi KRS.

6. Mengecek mata kuliah yang ditawarkan. Setelah membuka portal, tiap mahasiswa membuka menu informasi mata kuliah yang

\section{Artifacts}


ditawarkan, sesuai dengan semester yang sedang berjalan.

7. Mengisi KRS. Pengisian KRS ini bisa dilakukan jika mahasiswa telah memperoleh Kartu Hasil Studi (KHS) semester sebelumnya (untuk mahasiswa lama). Berdasarkan Indeks Prestasi (IP) yang didapat jumlah SKS dapat ditentukan. Mahasiswa akan mengisi KRS berdasarkan data dari informasi matakuliah yang ditawarkan.

8. Menghubungi dosen pembimbing. Setelah mengisi KRS, maka mahasiswa akan menghubungi dosen pembimbing, dan dosen pembimbing akan memeriksa KRS tersebut.

- Jika dosen pembimbing telah menyetujui pengisian KRS tersebut, pada saat kita mengakses portal akademik akan ada info bahwa KRS yang kita masukkan telah disetujui, dan dosen pembimbing akan menandatangani kertas KRS tersebut.

- Jika belum disetujui, maka mahasiswa harus segera menghubungi dosen pembimbing. Karena sebelum dosen pembimbing menyetujui KRS, nama mahasiswa yang bersangkutan nantinya tidak akan terdaftar dalam kelas yang telah dipihnya, atau jika dosen pembimbing tidak menyetujui pengisian KRS tersebut, maka mahasiswa harus segera melakukan revisi KRS tersebut.

9. Menunggu proses pengisian KRS Online. Setelah mengisi KRS secara manual, mahasiswa juga diwajibkan untuk melakukan pengisian KRS secara Online dengan memasukkan data KRS manual.

\subsection{Analisis Sistem Pengisian KRS Online}

Berdasarkan hasil analisis pada proses pengisian KRS Online Fakultas Teknik Universitas Sam Ratulangi kami telah membuat tahap-tahap dalam proses pengisian KRS tersebut. Tahap-tahapnya sebagai berikut:

1. Membayar SPP. Para mahasiswa diwajibkan untuk membayar SPP terlebih dahulu. Setelah membayar SPP, mahasiswa diminta untuk melakukan registrasi pada pihak Fakultas. Registrasi ini dilakukan dengan cara memberikan bukti pembayaran SPP (dalam bentuk slip pembayaran dari Bank).

2. Membuka portal akademik. Tiap mahasiswa telah diberikan Username yang berupa NRI dan password (ditentukan sendiri) untuk mengakses portal akademik untuk kelancaran proses pengisian KRS.

3. Memasukkan username dan password. Mahasiswa harus mengisi username dan password untuk dapat membuka portal dan mengisi KRS.
4. Memilih kartu rencana studi. Setelah membuka portal, mahasiswa akan memilih Kartu Rencana Studi pada menu Academic.

5. Mengisi KRS. Pengisian KRS ini bisa dilakukan jika mahasiswa telah memperoleh Kartu Hasil Studi (KHS) semester sebelumnya (mahasiswa lama). Berdasarkan Indeks Prestasi (IP) yang didapat jumlah SKS dapat ditentukan.

6. Proses pemilihan kelas dan dosen pengampu. Dalam proses pemilihan kelas dan dosen pengampu, ada angkatan yang penempatan kelasnya diatur secara otomatis dan ada yang dipilih secara manual.

- Jika kelas yang dipilih belum penuh, mahasiswa bisa mengontrak kelas tersebut

- Jika kelas yang dipilih sudah penuh, mahasiswa harus mencari dan mengontrak kelas lain yang belum penuh.

7. Menghubungi dosen pembimbing. Setelah mengisi KRS, kita harus memastikan apakah dosen pembimbing telah menyetujui pengisian KRS tersebut.

- Jika dosen pembimbing telah menyetujui pengisian KRS tersebut, pada saat kita mengakses portal akademik adakn ada info bahwa KRS yang kita masukkan telah disetujui.

- Jika belum disetujui, maka mahasiswa harus segera menghubungi dosen pembimbing. Karena sebelum dosen pembimbing menyetujui KRS, nama mahasiswa yang bersangkutan nantinya tidak akan terdaftar dalam kelas yang telah dipihnya.

8. Mencetak KRS. Setelah KRS telah disetujui oleh dosen pembimbing, maka KRS dapat dicetak.

9. Dosen pembimbing menandatangani KRS.

10. Pembantu dekan I menandatangani KRS

11. Kantor jurusan menerima selembar KRS yang telah ditandatangani sebagai arsip Fakultas.

12. Mahasiswa menyimpan selembar KRS yang telah ditandatangani sebagai bukti

\section{Kesimpulan}

Berdasarkan analisis kami mengenai pemodelan proses pengisian KRS manual dan online dapat disimpulkan:

1) Pengisian KRS secara manual kurang efisien. Karena dalam proses pengisian KRS manual mahasiswa harus berada di kampus untuk meminta formulir pengisian KRS. Hal ini tentu saja membuat mahasiswa yang mungkin berada jauh dari lokasi kampus (pulang kampung, berlibur, dll) tidak bisa mengambil formulir tersebut. 
2) Pengisian KRS secara manual bisa dikatakan lebih rumit. Hal ini dikarenakan dalam mengisi KRS manual, mahasiswa harus melihat terlebih dahulu tentang informasi mata kuliah yang ditawarkan, beban SKS, serta kelas yang nantinya akan dikontrak. (Pada langkah ke-6 dalam proses pengisian KRS manual)

3) Dengan BPMN pemodelan proses pengisian KRS bisa lebih mudah dimengerti dan lebih rapih.

\section{Daftar Pustaka}

[1] Tim Penyusun," Buku Panduan Akademik Tahun 2012/2013 Fakultas Teknik Universitas Sam Ratulangi " , Manado, 2012

[2] D. Rosmala dan Falahah, "Pemodelan Proses Bisnis B2B dengan BPMN (studi kasus pengadaan barang pada divisi logistik)", Seminar Nasional Aplikasi Teknologi Informasi SNATI, 2007, pp. J63-J64

[3] Tyatyol.(2012, Januari). BPMN (Bussines Processing Modelling Notation). Viewed 2013 September 24.[online].

Avaible: http://tyatyol.blogspot.com/2012/01/bpmnbussines-processing-modelling.html 


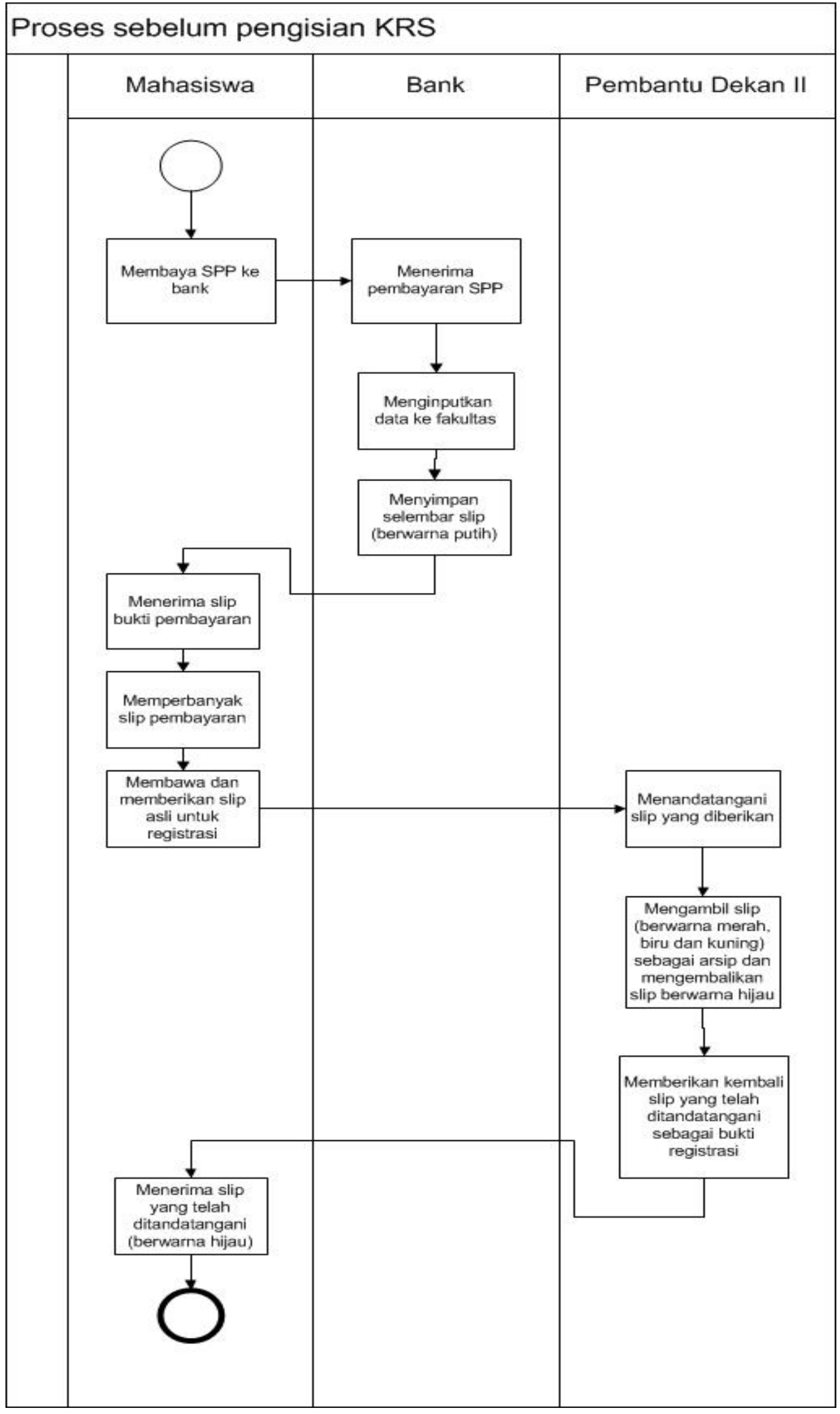

Gambar 10 : Proses sebelum pengisian 


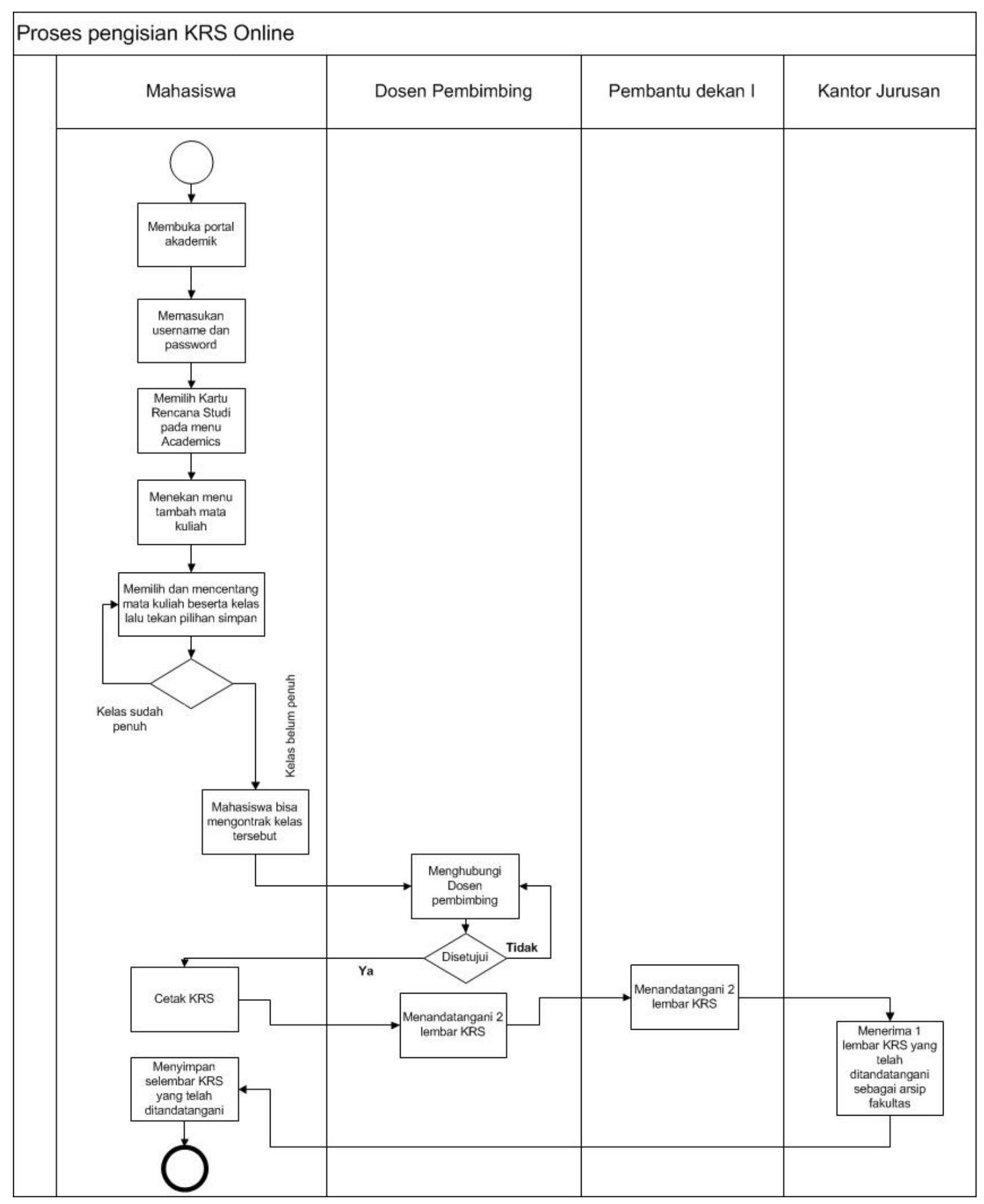

Gambar 11. Pemodelan sistem Online 